Summer 2004

\title{
Partition of Failed States: Impediments and Impulses
}

Thomas D. Grant

Wolfson College, Cambridge

Follow this and additional works at: https://www.repository.law.indiana.edu/ijgls

Part of the International Law Commons

\section{Recommended Citation}

Grant, Thomas D. (2004) "Partition of Failed States: Impediments and Impulses," Indiana Journal of Global Legal Studies: Vol. 11 : Iss. 2 , Article 2.

Available at: https://www.repository.law.indiana.edu/ijgls/vol11/iss2/2

This Article is brought to you for free and open access by the Law School Journals at Digital Repository @ Maurer Law. It has been accepted for inclusion in Indiana Journal of Global Legal Studies by an authorized editor of Digital Repository @ Maurer Law. For more information, please contact rvaughan@indiana.edu.

\section{$\Psi$}

JEROME HALL LAW LIBRARY

INDIANA UNIVERSITY

Maurer School of Law
Blooming ton 


\title{
Partition of Failed States: Impediments and Impulses
}

\author{
Thomas D. Grant*
}

\section{INTRODUCTION}

Failed states, not so long ago, were discussed as a problem of foreign aid or social theory. Only prescient thinkers and policy makers identified them as a priority of national security. The atrocities of September 11, 2001, did not make failed states a problem but very much did trigger recognition that severe civic dysfunction in one part of the globe might well have consequences elsewhere. An Afghanistan or a Somalia has first and final responsibility for its own future. At the same time, so widely can such a state spread disruption that 'its' affairs and 'ours' now can be said to be segregated only in a carefully qualified way. New alertness about national security has brought an unprecedented increase in creative analysis of the problem: What to do about failed states?

The predicate question - what is a "failed state?" - by no means lends itself to an easy answer. Like many questions involving statehood and international relations, the question of the failed state becomes more complicated the further one moves from the clear, core examples. It can little be controverted that Somalia and Afghanistan are in some important sense 'failed.' But, if characterization of a state as 'failed' may open the door to international intervention- - even, potentially, intervention that leads to radical revision of the contours of the state-then the criteria for that characterization are very important indeed, for their existence in a state would lead to the displacement of the important presumption of modern international law that the state enjoys legal autonomy and is the vehicle whereby its citizens realize their right to self-determination. Yet autonomy and self-determination well may be the very principles impelling intervention; states in the developed world may argue that their own rights are derogated when violent and uncontrolled forces arise in a failed state and disrupt public order in their territories.

\footnotetext{
*Thomas D. Grant is a Senior Research Fellow of Wolfson College, Cambridge University and a Fellow of the Lauterpacht Research Centre for International Law. His book, Recognition of States: Law and Practice in Debate and Evolution (1999), addresses how governments acknowledge change in the international community. He is currently working on a study of international law and the conflict in Chechnya.
} 
At least two problems present themselves. First, the definition of 'failed state' could be manipulated to justify intervention where the real object was not selfdefense but bald imperial gain. A pre-emptive notion of self-defense may extend foreign policy to the limits of international law, but empire building, under contemporary norms, plainly will find no principled justification whatsoever. Second, intervention, if unfettered by consensus as to the proper scope of the practice, could disrupt international order, as regional and global powers apply inconsistent standards in deciding where and when intervention is appropriate. Very tentatively, then, a failed state can be defined by reference to these criteria: ${ }^{1}$

(1) either no government exists or any government that does exist cannot discharge the international obligations of the state;

(2) no single government exists that can provide basic public order throughout the state territory, or most of it;

(3) public order in substantial parts of the territory of the state has broken down to the point where personal security is severely compromised and all or most forms of constructive, communal, or corporate activity are precluded by uncertainty and violence; and

(4) this state of affairs results not from transitory phenomena (famine, flood, short-term political crisis) but, rather, reflects an enduring systemic problem or problems unlikely to be resolved through limited, conventional measures, such as statutory reform by municipal lawmakers, new financial structures backed by international lending institutions, or material relief from donor countries.

It is clear from these tentative criteria that, though the state may continue to exist as a formal matter under international law-indeed, it often will in such cases $^{2}$ - severe pathologies disrupt its functioning in practice. Ancillary criteria may be considered in the situation, not at all rare, where a government subsists in some part of the territory of the state. For example, it may be relevant that the government must resort routinely to extreme violence to retain what purchase it has over the country; or that it has proved unwilling to abide or attempt to abide

1. See Jean-Germain Gros, Towards a Taxonomy of Failed States in the New World Order: Decaying Somalia, Liberia, Rwanda and Haiti, 17 THIRD WorLd Q'LY 455 (1996) (defining 'failed state').

2. And, accordingly, it usually will retain various formal indicia of statehood, such as membership in international organizations, diplomatic missions, and rights possibly arising from legal claims, such as claims to title to ter ritory, claims to the observance of obligations toward it by other states, etc. 
by international standards, particularly those relating to international security (e.g. arms control, denying safe harbor to terrorists). Again, the prospect for improvement by limited, conventional measures may be important in assessing the situation. And in any analysis of a particular case, each criterion will present its own questions of proof, these likely increasing in complexity the further the case is from the reasonably certain core of the problem of failed states. The concern of this article is to examine the constraints decision-makers face when wrestling with cases at least approximating the reasonably certain core.

Broadly, viewpoints on the problem have clustered around two pairs of competing conceptions. On the one hand, some analysts argue that existing states, their boundaries, and, to the extent possible, their constitutional structures, should be preserved; and that the United States and the West should make substantial outlays of money and also, in certain cases, of military resources, to achieve this preservation. On the other hand, it is argued that some states simply are untenable and that the rest of the world should disengage from their internecine conflicts and allow them, perhaps even encourage them, if they are so inclined, to dissolve into smaller, more manageable, pieces. Advocates of "nation building" and advocates of neutrality in the domestic affairs of states thus to a certain extent are also, respectively, advocates of preserving nations along extant contours and advocates of permitting radical revision of the structure of stateseven of partitioning them.

This clustering of viewpoints is evident in recent work on the subject. Radha Kumar wrote about Bosnia and Cyprus in Foreign Affairs in January 1997 and argued that partition is largely a failed strategy, associated with great powers dodging their responsibilities. ${ }^{3}$ Richard Betts in The National Interest in July 2001 argued that partition in the past has succeeded, at least in a relative sense, and would enable the United States today to free itself of the financial and other burdens associated with prolonged engagement in the Balkans. ${ }^{4}$

Kumar characterizes partition as an avoidance of responsibility. The postcolonial partitions of Cyprus, India, Palestine, and Ireland, in Kumar's view, indeed were abdications by the retreating colonial power, in those cases, Britain, and disasters for the countries involved. ${ }^{5}$ Betts, by contrast, sees partition as an

3. Radha Kumar, The Troubled History of Partition, 76 Foreign Afr. 22 (1997).

4. Richard K. Betts, The Lesser Evil: The Best Way Out of the Balkans, Nat'L Int., Summer 2001 , at 61 .

5. Kumar, supra note 3, at 24. 
acceptable, if by no means perfect, way to disentangle a policy of intervention from a situation defying graceful exit. ${ }^{6}$ Present arrangements in Kosovo and Bosnia, in Betts' view, are unsound; in that light the project now underway in Iraq likewise would draw question. It is in such places an external, at present mostly American, military force that keeps the peace. Partition, Betts ventures, would separate warring factions and possibly set the groundwork for a selfsustaining settlement. ${ }^{7}$

A full understanding of the problem requires, however, that policy makers broaden the discussion beyond these poles. While it is implicit in this discussion that partition as a strategy may have merit in some cases, it is not the purpose here chiefly to address the merits. To do so in full would require an excursion into political philosophy and cognate disciplines quite outside the scope of the present article. The aim here is to place partition, as a possible strategy to address the crisis of failed states, in a wider international legal and political context and thus to afford a better sense of the relevant possibilities and constraints.

\section{World War II And The Background of the Modern Crisis}

Like a broad swathe of human events since 1945, the crisis of failed states, too, has as its preamble the Second World War, a conflict that has both defined many of the problems of the last two generations and constrained the search for answers.

World War II, the greatest conflagration in human history, brought more than destruction in the battlefield of the armies of an axis of aggressor powers; more than the unconditional surrender of their leaders; more, even, than the subjection of their territories to foreign suzerainty. The six-year global struggle completely reconstituted the architecture of world security, with the victorious

6. Betts, supra note 4 , at $62-63$.

7. For further literature on the subject, see generally Nicholas Sambanis, Partition as a Solution to Ethnic War: An Empirical Critique of the Theoretical Literature, 52 WorLo PoL. 437 (2000); Nil Lante Wallace-Bruce, Of Collapsed, Dysfunctional and Disoriented States: Challenges to International Law, 47 Netherlands Int'L L. Rev. 53 (2000); Chinedu Reginald Ezetah, Legitimate Governance and Statehood in Africa: Beyond the Failed State and Colonial Self-Determination, in Legrtimate Governance in Africa 419-59 (Edward Kofi ed., 1999); Michael J. Kelly, Political Downsizing: The Re-Emergence of Self-Determination, and the Movement Toward Smaller, Ethnically Homogenous States, 47 Drake L. Rev. 209 (1999); Daniel Thürer, The 'Failed State' and International Law, 81 Revue Internationale de la Croix-Rouce 731 (1999). 
allies recognizing that traditional flashpoints of international instability had to be remade. ${ }^{8}$ The war itself occasioned developments of moment in virtually every field of human endeavor. The events that followed were nothing less than a political, territorial, and demographic earthquake. Where the totalitarian regimes of Germany and Japan had held their people in thrall and projected power out against neighbors and a wider world, new democracies, coupled with pacifist constitutions, were installed under the dual impetus of threat and reward. Throughout Eastern and Central Europe, and to a lesser extent East Asia, borders were changed, in certain cases revising radically the disposition of national territory. And chiefly in Eastern and Central Europe, the victorious powers impelled the movement of people.

Indeed, people were moved on a terrific scale. The immediate consequence in the Sudetenland, Pomerania, Silesia, and East Prussia was humanitarian disaster-though the losses were little discussed in the post-war period, owing, among other reasons, to a desire to avoid spawning a German irredenta. The short-term results for Poles and Ukrainians who were shifted about the map may have been less painful than for the Germans, but the process hardly lacked in brutality and privation. Survivors of the Holocaust, meanwhile, left Europe altogether for the New World and for the promise - and challenge- of building the State of Israel. An observation about the post-war contour of Europe is seldom made and then only with greatest caution: the demographic shifts effectuated after the war formed a cornerstone of an ethnic-national peace in Central and Eastern Europe of a depth and duration unprecedented in the region's history. This is an observation of cardinal importance and of potential relevance to present dilemmas of world public order. The reticence of historians and commentators about it cannot be explained alone by dissatisfaction over the results of the post-war revision, but rather by other factors, especially the means used to effect it. It does not go too far to say that the stability and security of Germany, Poland, the Czech and Slovak republics, the Baltic States, Ukraine-and thus of Europe as a whole-owe to acts that, if carried out later in the century, would have received universal condemnation as ethnic cleansing.

8. Throughout this article, I discuss stability in international order and stability in the internal order of societies. A question implied by this is how to balance stability and change at both levels in a way that maximizes human dignity. This question certainly cannot be answered without also considering how international and internal affairs influence one another. For a fascinating take on assumptions about international stability, see Ralph Peters, Stability, America's Enemy, ParaMETERS, Winter 2001, at 5 . 
Contemporary problems of global security, no less than many of the crises of the twentieth century, derive from clashes between communities of divergent perspectives, members of which by force of fate live in physical proximity to one another. Communities do violence to other communities over many forms of divergence; ethnic, linguistic, and religious divergences are prevalent examples. In numerous instances, the violence has reached proportions that the instruments of domestic governance cannot accommodate, and states themselves implode. Though the impact of such civic catastrophe is at first localized, deleterious consequences for the international system as a whole emanate from failed states. States and individuals who might participate in the world market to their advantage instead fall into isolation and want. Refugees flee, spreading instability to neighboring countries and straining social services and tolerance in countries farther afield. Territory of potential economic value, whether for manufacturing, for agriculture, or for raw materials, reverts to fallow. Multiple forms of strategic potential also go unrealized, as transportation corridors across the territory are obstructed and the state ceases to play any constructive role in international organizations and the international legal system. And, most dangerously, the collapse of the state gives rise to a power vacuum. In the past, this may have invited clashes between great powers, but, today, the greater threat is that violent, non-state groups will move in, feeding off the wreckage of the state they either displace or hijack. The terrorists who form such groups then use the territory of the failed state as a base from which to lash out at the international system they seek to destroy. ${ }^{9}$ Like a dead, collapsed star, the failed state ceases to cast useful light but disrupts with intense and malignant radiation a region of vast compass. Clashes between incompatible outlooks, originating in villages, towns, and countrysides in a land seemingly at the margins of international life thus can resonate dangerously through the framework of international security. In short, the local becomes global. ${ }^{10}$

It is certainly not the case that every crisis of a scope threatening local, regional, or global public order originates in a local group conflict. States with a comparatively homogeneous polity-as measured, for example, by prevalence in the state territory of a common language-have suffered exodus of refugees, collapse of governments, and widespread violence. Crises owing to hyperinfla-

9. See W. Michael Reisman, In Defense of World Public Order, 95 Am. J. INT'L L. 833, 833-35 (2001).

10. Consider the works of James N. Rosenau, for example, Along the Domestic-Foreign Frontier: Exploring Governance in a Turbulent World 70-73 (1997). 
tion (Germany and Hungary after World War I; Argentina in the 1970s) or environmental decay (present-day Bangladesh, the states of the Sahel) might invite programs of international assistance, but they are not necessarily the logical objects of the sorts of radical intervention that this article addresses. Rather, the problem here at issue is that of the degradation of public order triggered by conflict amongst groups possessed of mutually hostile collective identities.

Removal of inter-community friction by disaggregating communities in some cases has diminished conflict by a palpable degree. The tacit demonstration in the aftermath of World War II of the ameliorative-perhaps curativeeffect of such measures has failed by and large to inspire latter day remaking of states. To be sure, the concept of revising the demographic contours of a state or region has not been pushed entirely off the agenda. Academics have approached it from time to time-but with caution. " Among leaders actually making security policy, however, remaking states has been nearly taboo. The object here is to explain this-and to assess whether the remaking of states is likely to remain the essentially forbidden ground it has become.

Five distinct, if in places mutually entangled, reasons account for why the World War II settlement, in its aspect of the radical remaking of states, subsequently was little imitated. First, general presumptions of international law, in their profound conservatism, have coalesced to render the radical revision inherent in remaking states difficult or impossible to implement. Second, the putative right of persons displaced from their homes to go back has entrenched itself in recent years and presents a specific barrier at law to the demographic revision requisite in some cases to a meaningful remaking of a failed state. Third, remaking states in the past has been associated with gross violations of humanitarian law. Fourth, demographic revision, because it may involve creating homogeneous communities where they hitherto were mixed, meets with opposition in societies that value pluralism. And finally, financial burdens and political risks have daunted the powers positioned best to effectuate the remaking of states. These factors belong to a greater context of legal outlook and strategic architecturewhich themselves are governed by prevailing perceptions of risk and necessity. An

11. See Karin von Hippel, Democracy by Force: A Renewed Commitment to Nation Building, 23 Wash. Q., Winter 2000, at 95, 103-04; Chaim Kaufmann, Possible and Impossible Solutions to Ethnic Civil Wars, 20 Inr'L Sec. 136, 157-58 (1996); Chaim Kaufmann, When All Else Fails: Ethnic Population Transfers and Partitions in the Twentieth Century, 23 INT'L SEC. 120, 121 (1998); Kumar, supra note 3, at 24; Michael Mandelbaum, The Future of Nationalism, NAT'L InT., Oct. 1999, at 17, 20-21. 
important query ahead, discussed in Part II, is whether changes in the world militate toward a new approach to international law and international security and, moreover, whether the factors inhibiting the remaking of states will retain their old gravity. An analysis of these constraints, however, is prerequisite.

\section{A. Conservatism and the Sovereign State}

It is often said that one of the single successes of the United Nations era has been the fixing of international boundaries and widespread acceptance that these, as well as certain structures within the states they define, are to be altered only with the consent of all parties concerned.

Since the Peace of Westphalia, states have been the chief units constituting international society. It should come as no surprise, then, that the law of international society places a premium on rules having the aim to stabilize the identity and territory of states. If the states making up the international system rest on firm constitutional foundations and all parties have a good understanding of their geographic parameters, then the system benefits from greater certainty and is itself more stable. Since 1945 , the international system has very much installed as a rule the proposition that the external and internal contours of a state are inviolable. Article 2(4) of the U.N. Charter, prohibiting the use of force, goes to the inviolability of state frontiers. Article 2(7) protects the domestic jurisdiction of the state from external interference. This notion, an outgrowth of the sovereign supremacy of the state, has seldom been challenged, and almost never successfully, since its adoption. The instances are rare in which the Security Council has opened the way to coercive enforcement of international law by determining pursuant to Article 39 of the Charter that a breach of the peace has occurred. These all have related to aggression having the aim to wrest de facto control of a territory from a state or to extinguish a particular state altogether. ${ }^{12}$ In every

12. In particular, the cases refer to Korea, the Falklands, the Iraqi invasion of Iran, and the Iraqi invasion of Kuwait. See S.C. Res. 82, U.N. SCOR, 5th Sess., 473d mtg., U.N. Doc. S/INF/4/Rev.1 (1950) (complaint of aggression upon the Republic of Korea); S.C. Res. 83, U.N. SCOR, 5th Sess., 474th mtg., U.N. Doc. S/INF/5/Rev.1 (1950) (complaint of aggression upon Korea); S.C. Res. 84, U.N. SCOR, 5th Sess., 476th mtg., U.N. Doc. S/INF/5/Rev.1 (1950) (complaint of aggression upon Korea); S.C. Res. 502, U.N. SCOR, 37th Sess., 2350th mtg., U.N. Doc. S/RES/502 (1982) (Falkland Islands); S.C. Res. 598, U.N. SCOR, 42d Sess., 2750th mtg., U.N. Doc. S/NNF/43 (1987) (IraqIslamic Republic of Iran); S.C. Res. 660, U.N. SCOR, 45th Sess., 2932d mtg., U.N. Doc. S/RES/ 660 (1990) (Iraq-Kuwait). 
instance, the aggressor failed to alter the disposition of territory. Revision from without meets an effective bar under international law and practice.

From within, change is likewise inhibited. Proponents of an avant garde definition of "self-determination" argue, or at least imply, that secession is a right enjoyed by minority groups in states. ${ }^{13}$ Secession, however, as a matter of what might be called "positive" international law, is hardly an established right. ${ }^{14}$ From Quebec to Chechnya, states facing secessionist challenge have refused to accept an obligation to accommodate secessionist claims. Just as importantly, other states, observing secessionist crises abroad, have almost universally asserted that the right of the parent state to maintain and protect its territorial integrity in most circumstances supersedes any claim to independent statehood on the part of a sub-unit of the national polity. Even when sympathies lie with secessionists, support almost never extends beyond the humanitarian dimension. Recognition of a forcible and non-consensual change in the disposition of territory by elements within a polity is virtually unknown. A survey of state practice over the last six decades offers many cases of failed secession, and in all but one case of attempted secession (that of East Pakistan/Bangladesh), the attempt not only failed ultimately in practice, but also failed over its course to receive ratification from anything but an insubstantial minority of states. The bid by Biafra for statehood failed, receiving recognition from merely five states, none great or even middle-weight powers. ${ }^{15}$ The break-up of socialist states in the $1990 \mathrm{~s}$ resulted in the creation of a number of new states, but the preponderance of legal opinion is that secession was not the vehicle for their independence. ${ }^{16}$

13. See David Raič, Statehood and the Law of Self-Determination, 324-25 n.59. Raič makes a measured argument from state practice that a "qualified right of unilateral secession" has come into being under international law. See id. at 362-73.

14. James R. Crawford, State Practice and International Law in Relation to Secession, 69 Brit. Y.B. INT'L L. 85, 86 (1998).

15. Tanzania, Gabon, Côte d'Ivoire, Zambia, and Haiti recognized the breakaway region of southeastern Nigeria; but, it seems this was mainly as a humanitarian rather than a political gesture. John J. Stremlau, The International Politics of the Nigerian Civil War 124-41 (1977); David A. Ijalaye, Was "Biafra" at Any Time a State in International Law?, 65 AM. J. INT'L L. 551, 553-54 (1971).

16. In the case of the new states in the space of the former Soviet Union, consent of the "parent" state was at length won, with the Alma Ata Declaration, Annex II, at 5, U.N. Doc. A/47/60, S/ 23329 (1991). In the case of new states in the space of the former Socialist Federal Republic of Yugoslavia, consent of the parent state became a moot point, as the federal institutions at the heart of 
The lack of a legal right to secession is only one indicator of the strength of the principle that the state is inviolable. The international system as now constituted also resists changes in the structure of a state, even when the changes would be less profound than dissociation of parts of the polity. Attempts to redraw state boundaries even slightly seldom, if ever, take place without the consent of both states involved. Adjudication before the International Court of Justice or ad hoc arbitration has resulted in border changes, but such changes are inseparable from the consensual aspects of the dispute settlement process. The parties must agree for it to happen. Moreover, insofar as it has happened in the United Nations era, it has happened mostly at the margins-if not of the international system, then certainly of the territories of the states involved. Border changes, while in many cases very important to particular communities and even to governments, in a context of world public order have been mostly small, remote, and relatively contained in their systemic impact.

Finally, there are cases of purely internal changes in the constitutive order of a state. Here, too, consonant with Article 2(7), very little has happened, absent the consent of the local parties. The process of ascertaining whether local parties desire to alter their governing arrangements is one fraught with legal and political risk. International initiatives to restructure Haiti and Cambodia were greeted with ambivalence by scholars of international law-the 'leading publicists,' to use the expression in Article 38 of the Statute of the International Court, offering a divided opinion. ${ }^{17}$ The balance of opinion is indeed highly skeptical of intervention to remake states. Consistent with the prevailing ambivalence, very little has happened, where the local parties have not themselves been the initiators of the

the parent state disintegrated, thus ending that state as a functioning entity. There was, in short, nothing left from which to secede. Arbitration Commission of the E.C. Conference on Yugoslavia ('Badinter Commission'), Opinion No. 1, Nov. 19, 1991 and Opinion No. 8, July 4, 1992 (reprinted in 31 I.L.M. 1488, 1494, 1521 (1992)).

17. See Richard Falk, The Haiti Intervention: $A$ Dangerous World Order Precedent for the United Nations, 36 Harv. Int'L L.J. 341 (1995); Olivier Corten, La Resolution 940 du Conseil de Sécurité Autorisant une Intervention Militaire en Haiti: L'emergence d'un Principe de Légitimité Démocratique en Droit International? [Resolution 940 of the Security Council Authorizing a Military Intervention in Haiti: The Emergence of a Principle of Legitimate Democracy by International Right?], 6 Eur. J. INT'L L. 116 (1995); see also Arthur Paecht (General Rapporteur), Draft Special Report, Kosovo as a Precedent: Towards a Reform of the Security Council? International Law and Humanitarian Intervention, Civilian Affairs Committee, NATO Parliamentary Assembly, Sept. 16, 1999, available at http:// www.nato-pa.int/archivedpub/comrep/1999/as245cc-e.asp. 
change. Even consent of the state in question, then, may not be enough, in the contemporary understanding.

Legal opinion suggests that changes may require more than consent of the relevant local parties. They may require local initiative. But on a survey of the landscape of international practice, one may be forgiven for wondering whether the rule that has taken root is more restrictive than expressed by the words "no changes without consent" and more restrictive even than "no changes without local initiative." The record very much suggests that the received understanding is best expressed simply: "no changes."

It follows almost directly from the above that revision of the borders, constitutional structures, and demography of states has met with resistance. The frontier between Poland and Germany, fixed as a matter of demographic and political reality in 1945, did not achieve final recognition until 1990. The disaggregation of the Turkish from the Greek population in Cyprus, begun in 1963, was completed in fact with the establishment of a Turkish Republic of Northern Cyprus (TRNC) on November 15, 1983. The Security Council declared that the TRNC must be denied recognition, and every state except Turkey has observed the proscription. ${ }^{18}$ The emigration of Serbs from Kosovo and the establishment of much of that province as a nearly homogenous Albanian ethnic zone are realities that may well prove irreversible. Yet officials of the concerned international organizations and foreign ministries scarcely address these realities head-on. There is, correspondingly, a demonstrated preference to side-step questions of the future legal status of the territory. The international community is resistant to disaggregation, even in circumstances where events have cast doubt on the capacity of polymorphous communities to continue to exist as aggregates. Where disaggregation has nonetheless taken place, states resist sanctifying it with formal recognition of a change in legal status. Kosovo remains, in the view of the United Nations, NATO, and other participants in the peacekeeping operation there, a province of Serbia, ${ }^{19}$ much as the TRNC, following similar opinion, remains part of Cyprus. ${ }^{20}$ The inviolability of the territorial integrity of the state —even when the state has manifestly failed to meet basic obligations in the

18. U.N. Doc. S/16149, at 2 (1983); U.N. Doc. S/16550, at 2 (1984).

19. See U.N. Doc. S/RES/1244, at 6 (1999).

20. There are, of course, major differences between Kosovo and Cyprus. In the former, intervention and effective separation comprised a multilateral initiative eventually receiving endorsement, albeit post hoc, from the Security Council. In the latter, an invasion by Turkey was 
dimensions of non-aggression and respect for human rights-remains a presumption with force in international affairs.

\section{B. The Right of Return}

The 'right of return' has figured prominently in recent discussion -and in legal instruments-concerning the Balkans and other regions where ethnoreligious discontent has triggered bloodshed and chaos. Annex 7 of the Dayton Accords (Agreement on Refugees and Displaced Persons) provides that:

[a]ll refugees and displaced persons have the right freely to return to their homes of origin. They shall have the right to have restored to them property of which they were deprived in the course of hostilities since 1991 and to be compensated for any property that cannot be restored to them. The early return of refugees and displaced persons is an important objective of the settlement of the conflict in Bosnia and Herzegovina. ${ }^{21}$

This follows precedent. The General Assembly in 1948 had addressed the matter of Palestinian refugees and posited: "[T]he refugees wishing to return to their homes and live at peace with their neighbors should be permitted to do so at the earliest practicable date."22

Following on the Dayton Accords and earlier practice, the Kosovo crisis gave rise to official statements positing a right of return. The Foreign Ministers of the G-8 countries in May 1999 called for a "safe environment for all people in Kosovo and ... the safe return to their homes of all displaced persons and refugees" and the "[s]afe and free return of all refugees and displaced persons." $23 \mathrm{~A}$ right to safe and voluntary return has been noted, too, in connection with the

supported by no other state and condemned by many, including the Security Council. Similarity in result-withholding of legal recognition of a change in effective disposition of power-in view of the notable differences only underscores the force of the presumption of territorial inviolability.

21. General Framework Agreement for Peace in Bosnia Herzegovina, 75 I.L.M. 138 (1995).

22. G.A. Res. 194, U.N. GAOR, 3rd Sess, at para. 8, U.N. Doc. A/776 (1948); see also Lex Takmenberg, The Status of Palestinian Refugees in International Law (1998); John Quigley, Displaced Palestinians and a Right of Return, 39 Harv. INT'L L.J. 171 (1998).

23. Statement by the Chairman on the Conclusion of the Meeting of the G-8 Foreign Ministers held at the Petersberg Centre on 6 May 1999, G.A. Res. 1244, U.N. SCOR, 54th Sess., pt. 1, Annex 1, at 36, U.N. Doc. S/Res/1244 (1999). 
conflict in Chechnya. ${ }^{24}$ And the right is not restricted to specific refugee crises. General provisions, such as the Universal Declaration of Human Rights and the Geneva Conventions, have been identified as codifying an international norm on the return of refugees to their points of origin. ${ }^{25}$ Article 8 of the European Convention on Human Rights may further install a right of return in international law. ${ }^{26}$

International law writers sometimes express the view that intensification of an international law of human rights marks a move away from traditional notions of the state as primary entity in world public order and individuals as subjects of unrestrained government discretion. The right of return certainly belongs to the trend in human rights. At the same time, though, the right of return reinforces the status quo as to demographic dispositions and, in this, supports a fixed understanding of where states are, who forms the polities of a state, and how the institutions of governance in a state are constituted and maintained. As such, the right of return belongs just as much to the conservative tradition surrounding the immutability and inviolability of the state. Disaggregation of feuding members of divergent communities runs headlong into the right of return, and freedom of movement, often viewed as concomitant with the right of return, makes any disaggregation already undertaken impossible to perpetuate.

Neither the prevailing conservatism of international law with respect to the identity and structure of states nor the spread of human rights norms into matters once viewed as the exclusive domain of national jurisdiction have gone

24. United Nations, Economic and Social Council, Commission on Human Rights, Situation in the Republic of Chechnya of the Russian Federation, Report of the High Commissioner for Human Rights Submitted in Accordance with Commission Resolution 2001/24, U.N. Doc. E/CN.4/2002/38, at paras. 67-74 (2002).

25. Specific texts often cited to that effect include the Universal Declaration of Human Rights, G.A. Res. 217 A (III), at art. 13 (1948) ("[e]veryone has the right to leave any country, including his own, and to return to his country"); Universal Declaration of Human Rights, G.A. Res. 217 A (III), at art. 15 (1948) ("[e]veryone has the right to a nationality"); Convention Relating to the Status of Refugees, U.N. Conference of Plenipotentiaries on the Status of Refugees and Stateless Persons, U.N. Doc. A/1775 (1950); International Covenant on Civil and Political Rights, G.A. Res. 2200 A (XXI), U.N. GAOR, 21st Sess., at art. 12 (1966); Geneva Convention for the Amelioration of the Condition of the Wounded and Sick in Armed Forces in the Field, Aug. 12, 1949, 6 U.S.T. 3152 (art. 63); 6 U.S.T. 3254 (art. 62); 6 U.S.T. 3424 (art. 142); 6 U.S.T. 3622 (art. 158).

26. For a contemporary discussion of the return of refugees, see Joan Fitzpatrick, Temporary Protection of Refugees: Elements of a Formalized Regime, 94 AM. INT'L L. 279 (2000). 
without criticism. ${ }^{27}$ However, through the 1990 s, nothing compelled a mass of decision makers to revisit the assumptions that had formed the foundation of the security architecture of the Cold War or its juristic corollaries. That architecture had served its purpose well and, though it was understood so widely that it fast became cliché to observe that "the Cold War has ended," the specific impetus for a new approach to security did not arise. Most features of the international legal system too remained unchallenged even after transformation of the environment in which those features had evolved.

Conservatism employed an internal calculus like this: A full-scale clash between superpowers would have resulted in global holocaust or, at least, the collapse of international order. There were numerous revisions that either superpower might have wanted to effect in the structures of individual states or regions. However, restructuring at the micro-level risked conflict at the superpower level. Cold War strategists understood that World War I had had something to do with the conflict over Sarajevo and World War II with Danzig. Any benefits that the United States or the Soviet Union might have derived from local restructuring the two powers judged to be outweighed by the risks of the global conflagration that such restructuring might have ignited. The superpowers thus agreed on an international regime of non-change. This conserved boundaries, demographic dispositions, and in most states even domestic constitutional structures. In so doing, it enhanced security in a system dominated by a pair of powers with heightened military preparedness and a desire, however much one might have sought ideological prevalence over its competitor, to avoid open warfare and the wrecking of international order.

Conservatism offers nothing, however, to constituencies that believe they have no stake in society in its present form. Such constituencies once posed little threat outside their localities. Now, however, the situation is much different. The proliferation of technology, the porosity of international frontiers, and the openness of western societies mean that constituencies with radical revisionist

27. See, e.g., Steven R. Ratner, Drawing a Better Line: Uti Possidetis and the Borders of New States, 90 Ам. J. INT'L L. 590 (1996) (examining the propriety of uti possidetis to contemporary challenges related to state unity); Tomás Bartos, Uti Possidetis. Quo Vadis?, 18 Austr. Y.B. INT'L L. 37 (1997); Obiora Chinedu Okafor, After Martyrdom: International Law, Sub-state Groups, and the Construction of Legitimate Statehood in Africa, 41 Harv. INT'L L.J. 503, 526-27 (2000); John A. Gentry, The Cancer of Human Rights, 22 WASH. Q., Autumn 1999, at 95 (arguing that "[t]he unbridled growth of human rights accentuates differences among persons and groups, threatens internal order and social cohesion, and transforms nations into mere states."). 
aims can pursue those aims any where and with violent effect. In face of this, conservatism starts to lose its coherence as an ordering theory.

Human rights law is welcomed as part of the 'progressive development of international law.' Progressive in some senses it undoubtedly is. However, the right of return, so strongly posited during the United Nations era in treaty, practice, and theory, contains a substantial conservative element. A community disrupted by warfare or civil disturbance, under the right of return, possesses, qua community, a right to re-assemble itself in its old form. The displacement of persons thus is never more than temporary. While this certainly involves the strengthening of the rights of individual human beings, it just as much strengthens the presumption that population groups as a whole are stable entities fixed in place and sovereign allegiance. The right of return well may deter would-be perpetrators of ethnic cleansing. If the right of return is firmly established-and enforced-then seizing territory and driving away uncooperative inhabitants offers no profit to the aggressor, for the inhabitants well may come back. But in addition to deterring ethnic cleansing, the right of return carries with it a calcifying effect upon the dispositions of people in a given territory and is thus a helpmate to conservatism in the identity and structure of states.

\section{The Specter of Ethnic Cleansing}

Any proposal to move people, even if in pursuit of acceptable goals, meets a powerful objection: "moving people" in the past has almost always meant ethnic cleansing. Advocates of a more robust system of international criminal justice identify ethnic cleansing as one of the main crimes that the system should deter and punish. ${ }^{28}$ States responsible for interventions in Bosnia, East Timor, and Kosovo justified these as responses to ethnic cleansing. And non-intervention in Rwanda was decried as a policy failure, permitting in that country one of the most brutal exercises in ethnic cleansing to date. It is further suggested that establishing a plain rule that ethnic cleansing will not be let stand will in turn deter aggression more generally. Reversing ethnic cleansing takes the profit out of

28. See David J. Scheffer, International Judicial Intervention, Foreign PoL'y, Spring 1996, at 34, 36 (noting in particular that the Rwandan and Yugoslav criminal tribunals have jurisdiction over charges of ethnic cleansing); Theodor Meron, Answering for War Crimes: Lessons from the Balkans, Foreign AfF., Jan./Feb. 1997, at 2. 
aggression. ${ }^{29}$ The Vance-Owen Peace Plan, put forth early in the conflict in Bosnia, was widely rejected on grounds that it sanctified forced population transfers and thus rewarded aggression. ${ }^{30}$ On a more reflective note, one commentator suggests that ethnic cleansing is the price for forgetting about history. ${ }^{31}$ Ethnic cleansing was so much a bane of twentieth century international life that any instrumentality bearing resemblance to it is bound to be presumed infirm.

The expulsion of Germans from the Sudetenland, commenced in May 1945 and carried on through the summer, resulted in the deaths of at least 30,000 and perhaps as many as 250,000 . The victorious powers had agreed at Potsdam that German populations could be removed from their homes in Eastern Europe as part of the post-war settlement. Though the powers stipulated that any such resettlement program be undertaken with provision for the rights of the persons resettled, violence was in fact the main mechanism at work in the months after cessation of armed conflict. The result was antagonism between Sudeten Germans and Czechoslovakia-a factor sometimes complicating relations between the Federal Republic of Germany and the Czech Republic. ${ }^{32}$ Judging from the example of the Sudetenländer, redistribution of ethnic groups can produce local stability in place of crisis. However, if not properly managed, it can simultaneously export at least certain residual tensions to other arenas.

The continuing rancor that surrounds many of the resettlements that have taken place over the last hundred years owes to the mechanisms used to achieve them, at least as much as to the fact of resettlement itself. Even where resettlement may have taken place with less bloodshed than in Central and Eastern

29. See Charles William Maynes, Relearning Intervention, ForeIGN PoL'y, Spring 1995, at 96; see also S.C. Res. 787, U.N. SCOR, 3137th mtg., at 2, U.N. Doc. S/RES/787 (1992) (noting that "any taking of territory by force or any practice of 'ethnic cleansing' is unlawful and unacceptable, and will not be permitted to affect the outcome of the negotiations on constitutional arrangements for the Republic of Bosnia and Herzegovina"); G.A. Res. 3314, U.N. GAOR, 29th Sess., Supp. No. 19, at 144, U.N. Doc. A/9619 (1974) (noting that "[n]o territorial acquisition or special advantage resulting from aggression is or shall be recognized as lawful"). Article 7 of the Rome Statute of the International Criminal Court includes within its definition of crimes against humanity "deportation or forcible transfer of populations." Moreover, the Statute cites broadly as crimes racial, religious, and linguistic discrimination. Rome Statute of the International Criminal Court, arts. 6, $7(1)(h), 7(2)(f)$, and $21(3)$.

30. See Noel Malcolm, Bosnia and the West: A Study in Failure, THE NAT'L INT., Spring 1995, at 3.

31. See Ian Gambles, Lost Time: The Forgetting of the Cold War, ThE NAT'L INT., Fall 1995, at 26.

32. See Timothy W. Ryback, Dateline Sudetenland: Hostages to History, Foreign Pol'y, Winter $1996 / 1997$, at 167. 
Europe, lack of proper compensation exacerbates old frictions. Resettlement without affirmative inducement perpetuates crisis. The stabilizing effect of the remaking of the ethnic outlines of places as diverse as Cyprus and the Sudetenland is easily overlooked, in the shadow of the tolls on the people subject to resettlement.

What if radical territorial and demographic revision could be effected without exclusive reliance on force? What if material inducements, rather than physical threats, provided the impetus for change? With material support from a sponsoring power, the remaking of a state in the demographic dimension conceivably could take place in peaceful fashion. Convincing assurance would have to be furnished that the means to the state-remaking end did not repeat the mass deprivation caused by involuntary movement of populations in the past. Only a power or alliance of powers able and willing to assume the cost of such an assurance could undertake the remaking of a state on requisite scale. The costs would make a multilateral organization of broad constitution the most likely candidate to undertake such an enterprise, and the need to legitimate it in the eyes of the population most directly concerned might also militate in favor of leadership by the United Nations or at least a prominent regional organization such as the EU, Organization for Security and Co-operation in Europe, Organization of the Islamic Conference, Organization of American States, or African Union. A multilateral approach might also be conducive to establishing transparent mechanisms for the effectuation of the proposed revisions; full public communication about the process might increase confidence in it. The steps necessary to avert a crisis worse than the one the policy aimed to cure would have to be far-reaching and elaborate. And even if, through such steps, population transfers were effectuated without precipitating humanitarian disaster, still other factors inhibiting the remaking of states would remain for leaders to address.

\section{Pluralism Transposed}

Resistance against remaking states arises because the methods employed in the past have violated human dignity. Resistance also arises because disaggregating diverse communities does violence to pluralist principles that western leaders aim to universalize.

To question the transposability of pluralist values is a delicate exercise, if not altogether hazardous, because some of the most important political formations of the present day - not least of all, the United States and the European Union- 
are predicated on pluralist values; and, when the transposability of those values had been rejected in the past, it was not infrequently in the service of deplorable political ends. An archetypal attack on union in diversity was the Separate Opinion of the South African Judge ad hoc in the South West Africa case (Second Phase), which stated, inter alia:

When universal franchise is introduced into a fairly homogeneous society there is a reasonable prospect of success, even where the general standard of development of the electorate is fairly low. But when various national groups differing widely as to physical appearance, ethnic stock, culture, language, and standards of development are being integrated into the same political system, failure seems to be inevitable. The tensions, uncertainties and disharmonies which arise from attempts at assimilation of peoples with gross dissimilarities are strong enough to doom to failure any schemes that the ingenuity of man may devise. ${ }^{33}$

What precisely the historical evidence was to corroborate the assertion that "failure seems to be inevitable" is beside the point. Its salience is in its tendentiousness; in its character as an apology for the National Party policy of Apartheid as practiced in the mandated territory of South West Africa (Namibia); and in its fouling of any attempt to rationally approach a question of importance in an era when massive international interventions are underway with the aim of democratizing places as diverse and inexperienced in pluralism as Iraq and Afghanistan. Debate over a policy that aims to extend pluralist values beyond their solid Atlantic base thus has focused almost entirely on certain limited historical examples.

Among decision makers in government and those who participate actively in debates over foreign policy, the example of American intervention after World War II in the affairs of the vanquished powers serves as touchstone. Two societies, one in Europe and one in Asia, had succumbed to a hypertrophied militarism in contradiction with the progressivist assumptions of nineteenth century political thinkers. America and her allies defeated Germany and Japan and

33. South West Africa (Ethiopia v. South Africa; Liberia v. South Africa) (Second Phase), Sep. Op. Judge ad hoc Van Wyk, 1966 I.C.J. Reps. 67, 190-91, para. 40. 
then followed military victory with a program far greater in its scope and aims than any ordinary campaign-at-arms. Material aid in unprecedented quantity was directed to the former adversaries, and, using the dual impetus of this seeming charity and an army of occupation, the United States re-fashioned Germany and Japan, if not precisely in its own image, then in conformity with many of the pluralist principles already deeply embedded in the American psyche in 1945. It is this model that many believe can be replicated on a universal scale.

Belief in the transposability of pluralist values is deeply entrenched in American foreign policy, yet it arguably merits more scrutiny than it has received to date. Two considerations may lead policy makers to qualify the view that, if pluralist values could be transposed to Germany and Japan, then they can be transposed anywhere. Very importantly, both aggressor powers in World War II possessed formidable infrastructures for education, industrial production, and social welfare. Though pummelled in the conflict, both states were to a remarkable extent at the end of the war either intact or capable of rapid repair. Along with such physical and institutional assets, both countries possessed long traditions in many fields crucial to national recovery. The United States, in short, had a great deal on which to build.

Just as importantly, both countries benefited from a general social peace within their boundaries. This owed in part to the overwhelming presence of an occupying army, the prestige of which was enhanced by the unambiguous victory it had achieved over the indigenous fighting forces. However, this benefit owed also to acts of disaggregation of divergent communities, done in the case of Japan long before America even had had contact with that country and in the case of Germany by the totalitarian regimes of Hitler and Stalin. Japan possessed a population that believed itself markedly more homogenous than other nations. ${ }^{34}$ And Germany entered its period of post-war reconstruction dissociated from the minority populations within and co-ethnic populations without that had been objects of destabilizing inter-community and international conflict.

Complexity is added to the relationship between pluralism and failed states by the centrality of pluralism to American thought. The United States, as the leading power of the present era, telescopes its preferences and beliefs very effec-

34. It is widely noted that Japan is not as homogeneous ethnographically as many Japanese often claim. See, e.g., Multicultural Japan: Palaeolithic to Post-Modern (Donald Denoon et. al. eds., 1997). Community self-perception exercises a force at times as powerful as fact. 
tively onto the world stage. ${ }^{35}$ As a very large state, and a very successful one in every dimension in which the success of a state might reasonably be measured, the United States contains a citizenry whose limited contact with the outside world sometimes stands in astonishing contrast to their material, technological, cultural, and spiritual accomplishments. Not only do many Americans scarcely think about places lacking the attributes that have led America to success; they find it difficult, when they do think about such places, to believe that American values cannot be installed there to remedy local ills. ${ }^{36}$ Statements by President Clinton in relation to intervention in the Balkans iterated in strong form the American dedication to pluralist ideals. Characteristic of the President's language were phrases such as "stable, multiethnic democracy," "forces of tolerance and freedom," and "tolerance takes root in the Balkans." ${ }^{37}$ These statements could scarcely have been expected to resonate through the calcified hatreds of the war-torn provinces, and, to individuals familiar with the dynamic of intercommunity 'relations' in the region, they sounded, at best, optimistic.

35. This has not met with universal acclaim. Consider the controversy over the extraterritorial application of United States federal laws. See Michael P. Malloy, United States Economic Sanctions: Theory and Practice 290 (2001); Kenneth A. Rodman, Sanctions Beyond Borders: Multinational Corporations and U.S. Economic Statecraft 23 (2001).

36. That segment of the American population which, through the global expansion of United States-led business, has had extended contact with cultures outside the United States may be an exception to the rule. However, not all members of that segment are an exception, and, even insofar as they are, it may not matter. The success of American enterprise abroad often involves the preservation of American management theory and culture in business organizations, even as it adapts incrementally to local conditions. It is hardly the case, then, that all Americans abroad are immersed in local institutions. Moreover, the success of a business is measured in terms that may not be applicable to a political system; and good management practice may yield dividends in nearly any society that permits business activity in the first place. The evident eagerness of societies outside the United States to embrace American cultural products and American business management theory even may produce the deceptive impression on Americans overseas that all incidents of American society and politics can readily be transposed abroad. At any rate, the segment of the American population with substantial exposure to non-U.S. societies seldom has exercised a determining influence on U.S. foreign policy.

37. See President's Remarks on Presenting the Presidential Medal of Freedom, 36 WeekLY Comp. Pres. Doc. 1809, 1811 (Aug. 9, 2000); President's Remarks on the Situation in Yugoslavia and the Legislative Agenda and an Exchange with Reporters, 36 Weekly Comp. Pres. Doc. 2349, 2355 (Oct. 6, 2000); see also Office of the Press Secretary, Fact Sheet on Building a Durable Peace in Bosnia (July 30, 1999), available at http//ftp.fedworld.gov/pub/w-house/0731-3.txt (emphasizing return of minority refugees in Kosovo and Bosnia and emphasizing "ethnic reconciliation" and "multiethnic life" in the territories). 
Americans are confident that pluralism can be transposed overseas. In their dedication to the idea of the transposability of pluralism, they reveal not just a vision of foreign affairs but the heart of national self-identity. Americans through their history sacrificed a great deal to give life to the words in the second paragraph of the Declaration of Independence: "that all Men are created equal." Arguments among historians continue as to the relative weight of different causes of the American Civil War, but it would be facile to dismiss the argument that the Civil War contained an element of crusade and that the object of this was to end slavery. ${ }^{38}$ The Civil Rights Act of 1964 and the ensuing programs of the Great Society triggered upheaval and consumed immense resources. The goal, there too, was to make peace and prosperity reign across the divides of ethnic difference. Immigration-and from an ever-expanding orbit of countries-is the dominant fact of American demography. And the dominant fact of the history of American territory is expansion-from thirteen beleaguered colonial enclaves on the Atlantic seaboard to a continental republic. All along the way, the principle that the United States was a nation built out of many diverse and even divergent components- - pluribus unum-remained very much in force and even grew in strength. The origins and history of the United States render inevitable an almost theological devotion to the concept of the plural society. Insistence by American decision makers that pluralism be transposed-and is transposable-to other societies is a natural outgrowth of that devotion.

Western countries have achieved levels of material comfort, individual freedom, and societal security unparalleled in any other expanse of the globe. The impulse is pervasive to attribute causal effect to things that coincide with noteworthy accomplishments. This is not to say that celebrating pluralism is the socio-political equivalent of the lawyer wearing a lucky necktie to trial. It is important, however, to consider that the pluralist values that for the most part prevail in America and Western Europe bear a rather complex relationship to material and other social accomplishments. It may well be that a system like a feedback loop is involved, with tolerance and accommodation of divergent communities accelerating economic growth; and material comfort and opportunity in turn making most citizens unlikely to take the risk and expend the energy to commit hostile acts against their neighbors. It may well also be that the process only takes place after a certain base of material comfort and security is attained.

38. See Judith N. Shklar, American Citizenship: The Quest for Inclusion 22-23, 82-83 (1991). 
Outside America and Western Europe, many polities lack the bare essentials for stable existence. The chief objective for many states, then, is simply to secure society against existential threats such as famine and civil war. Exchange of opinion within the organs of government may have utility in such states; the ossification and corruption that ensue from the cronyism of a dictator's yes-men have all too often impeded development in states needing it most. But freeflowing debate in the general arena of the polity may well damage the collective interest, when the institutions and habits of the polity cannot accommodate divergent viewpoints. ${ }^{39}$ Even in states with the most developed institutions of democratic governance, public emergencies from time to time have necessitated some curtailment of rights and privileges. Countries where those institutions are least developed-and where crisis is routine-do not necessarily benefit from trying to replicate right away the standards prevailing in North America and Western Europe. Even countries that survive-but struggle to excel-have found benefit in approaches to governance that are less plural than others. Social and economic controls and governance displaying a "democratic deficit" that could hardly be tolerated in North America or Western Europe have been seen as valuable at different times in places as diverse as Singapore, Chile, and Turkey. Whether societies facing destitution and worse can reasonably be expected quickly to achicve the fullest expression of pluralist ideals is a question that policy makers may well ask in face of the new reminders of the global ramifications of the failure of states.

\section{E. Cost}

The financial burdens and political risks associated with interventions of the scope and duration necessary to effectuate the remaking of a state pose a powerful deterrent to governments. Measured as a percentage of gross domestic product, expenditures on foreign aid by the United States dropped markedly at the end of the Cold War. The boldest and furthest-reaching aid plan ever, the Marshall Plan, consumed an astonishing share of American productive output from its inception in 1948 through its conclusion in 1952. The outlays proposed for aiding the former Soviet and Yugoslav states in the 1990s were small by comparison. Political con-

39. See Amy L. Chua, The Paradox of Free Market Democracy: Rethinking Development Policy, 41 Harv. Int'L L.J. 287, passim (2000); Markets, Democracy, and Ethnic Conflict, 93 Am. Soc. Int'l L. Proc. 1 (1999). 
sensus for expenditures overseas disintegrated when the threat of an empire with hegemonic ambitions similarly disappeared. ${ }^{40}$ The political entanglements inherent in remaking states exerted a further deterrent effect. American public opinion reflected indifference or hostility to proposals that American armed forces be deployed to aid in the remaking of Haiti, Bosnia, Kosovo, and East Timor. ${ }^{41}$ In the United States, George Washington's parting advice to "steer clear of permanent alliance with any part of the foreign world" and Thomas Jefferson's inaugural aspiration urging "honest friendship with all nations-entangling alliance with none" have echoed through centuries of international relations politics. ${ }^{42}$ When asked to pay for foreign adventure, Americans generally have demurred.

Cost, like power in international affairs, however, has relative aspects. Cost can be measured against available resources, and cost can also be measured against the benefits an expenditure is expected to bring or harms it is expected to avert. A shift in perception about possible benefits or possible harms thus may bring about just as much change in how decision makers assess a proposed expenditure as fluctuations in available resources. Intervention overseas is not always cheap relative to resources available, perhaps requiring expenditures equating to a non-negligible percentage of a national budget. However, certain security risks are of such magnitude that expenditures made in their mitigation are said to be modest in terms relative to the risk. Perception of cost may vary with the perception of need to incur the cost.

There is little doubt that after September 11, 2001, decision makers in the United States experienced a shift in perception over security. To be sure, prescient observers had earlier expressed certainty that a heinous atrocity, sooner

40. Note however that a slope-off in support for foreign aid was recorded before the end of the Cold War. Total foreign aid from the United States to the developing world in the 1990s, expressed in relation to U.S. GDP per annum, hovered around 0.2 percent. See Robert E. Wood, From Marshall Plan to Debt Crisis: Foreign Aid and Development Choices in the World ECONOMY I-2 (1986).

41. On the political constraints on intervention, see Stephen J. Solarz \& Michael E. O'Hanlon, Humanitarian Intervention: When Is Force Justified?, WASH. Q., Autumn 1997, at 3. For a representation of skepticism toward interventionist foreign policy, see Ted Galen Carpenter \& Amos PerImutter, Strategy Creep in the Balkans: Up to Our Knees and Advancing, 44 NAT'L Int. 53 (1996).

42. President George Washington, Farewell Address, (Sept. 17, 1796), reprinted in Speeches of the American Presidents 17, 24 (Janet Podell \& Steven Anzovin eds., 2d ed. 2001); President Thomas Jefferson, Inaugural Address (Mar. 4, 1801), reprinted in Thomas Paine \& Thomas Jefferson, Paine And Jefferson on Liberty 139, 142 (1988). 
rather than later, would be perpetrated against Americans on their own soil. ${ }^{43}$ Only the event itself however precipitated the broad shift in outlook prerequisite to a shift in action. So graphically were the results of the terrorist attacks communicated that scarcely any corner of the polity questioned the need for vigorous action to reduce the risk of future attack. Action has included military intervention to change regimes in two states, and substantial increases in military and non-military aid to a number of other states. Insofar as terrorism thrives on the wreckage of failed states, the impetus has grown for making the repair of failed states part of the national security agenda. Insofar as unmanageable combinations of mutually hostile communities have caused states to fail, revision of the demographic structure of states may well come to be entertained more than before. As suggested above, large-scale displacement of persons and their resettlement in places remote from their origins has seldom occurred without an element of compulsion, and in many cases the compulsion has escalated to mass killing. Remaking states carries no small risk and recalls the darkest chapters of history. The present crisis, however, is spurring policy makers and informed bystanders alike to contemplate alternative approaches to security that a short time ago fell outside the parameters of mainstream debate.

In the past, the powers inducing population movement have typically themselves been under duress and have lacked the resources to manage the endeavor in ways conservative of human dignity. The Soviet Union after World War II faced severe privation and the task of internal reconstruction. The forced deportations from Central and Eastern Europe did not take place with reference to the interests of the persons deported. A much different model for remaking the demographic structure of a state or region can be envisioned however. Mobilized by the threat that failed states will continue to spawn terrorist fanaticism with direct and painful consequences, the United States and other powers well might appropriate resources sufficient to render programs of mass resettlement essentially pacific. The overwhelming majority of people likely to require resettlement live under dire conditions. This means that material support, if it modestly

43. "On his watch, my son [a Marine second lieutenant] is likely to see a weapon of mass destruction event. Another Pearl Harbor will occur in some city, somewhere in the world where Americans are gathered .... it will forever change him and his institutions." General Anthony Zinni, Speech to U.S. Naval Institute, (July 25, 2000), available at http://public.scott.amc.af.mil/; see also William S. Lind et al., The Changing Face of War: Into the Fourth Generation, 73 Mar. Corps Gaz. 22 (1989). 
exceeded subsistence requirements, might well secure cooperation. Targeted inducements of greater scale might be necessary to persuade key representatives of the effected communities. Perhaps some would refuse to support the envisaged demographic revision under any circumstances. The temptation to resort to coercive measures would hang heavily over such a policy. But, in places where the material bases for existence are eroded to a catastrophic extent, the generous rewarding of individuals for relocating in the interests of stability could conceivably achieve much of the goal. Unlike the USSR or other powers that, in the past, have coerced people to move, the United States and its allies today have the benefit of psychological detachment from events-even if only a relative detachment - and access to vast material resources. ${ }^{44}$

The expenditures necessary to effect the remaking of states which have failed and which, in their failure, pose a continuing threat to international security, would exceed the scope of recent foreign aid. Rebuilding physical infrastructure, a critical element of remaking a truly shattered state such as Somalia or Afghanistan, would consume substantial resources. Establishing the predicate internal security for such rebuilding would also be costly, perhaps in blood as well as treasure. It was not by meeting the totalitarian regimes of the twentieth century halfway that the United States put itself in the position to remake the states and societies those regimes had terrorized, and military force has not been ruled out as a predicate to remaking the failed states of the present. Military campaigns and ongoing intervention are at least as costly as the rebuilding programs that must ensue. Catalyzing the growth or recovery of local institutions of governance, education, and civil society would also take a commitment of funds on an enormous scale.

Demographic restructuring could be even costlier still. Geography may be immutable, but where people live most certainly can be changed. History is replete with examples. A central reason these have not become a model for addressing contemporary crises of state failure is that the process of resettlement often was indistinguishable from murder. Crises of internal cohesion and stability, however, have resulted, too, in violence and death on a massive scale and render vastly more difficult and expensive, if not altogether impossible, all other aspects of remaking a state. And the experience of more than one violencewracked territory has shown that cohesion and stability are elusive, when

44. A radical change in either dimension-toward greater psychological proximity or a decline in national wealth-would, of course, change the calculus. 
communities bearing deep-seated mutual enmities find themselves locked by geography in fatal embrace.

The cost of effectuating mass resettlement would be very high, if the burden were not to rest disproportionately on the people being resettled. Total expenditure on the demographic aspect of remaking a state would equate to a multiple of the number of persons displaced and resettled. The multiplier would be some monetary amount, calibrated within the program of displacement and resettlement to induce maximum cooperation by the people affected. It must be borne in mind that, in the countries for which such a program would even be deliberated as a policy choice, social, economic, and political systems are fractured to the point that conventional approaches to repair are plainly futile. If endeavored amidst a peaceful and prosperous population in North America, Western Europe, or East Asia, demographic revision would require, per person effected, a very large sum. Even amidst populations in the middle-income countries that have achieved basic development, such as Mexico or Thailand, the multiplier would be more than negligible. But where such restructuring in fact might represent an option, peace and prosperity are practically unknown. The multiplier accordingly would be a smaller sum.

The multiplier itself would equate to the sum of at least three distinct but related quantities:

C-Compensation for real property and other fixed assets relinquished by the individuals who are resettled, as well as for any lost value of businesses as going concerns, averaged for all members of the community identified for resettlement;

$P$-Average real income per person (within the community identified for resettlement) averaged over the calendar periods of the previous five years corresponding to the period during which economic activity is disrupted;

$I$-Affirmative inducement, above and beyond $P$, assessed as likely to secure individual compliance with the resettlement program.

Additional costs would be incurred in the administration and enforcement of resettlement. Administration would include mechanisms to adjudicate contests over the value of real property and other fixed assets, as well as accounting systems to assure delivery of payments of appropriate size to the appropriate individuals. Enforcement would consist of a military presence, extending forward from the operations necessary to set the table for the remaking of the state in 
question. Conventional police would take over from the military as conditions permitted. Models for this cost component might be derived from the United Nations missions for the administration of Kosovo and East Timor and the multi-power presence enforcing the peace in Bosnia. Models for the administrative and adjudicatory structures might be drawn from the Holocaust claims settlement process. The cases that produced these proposed models themselves suggest the complexity and duration of a full-scale program to remake a state.

Designating the number of individuals resettled under the program as $X$ and administration and enforcement costs for one year as $\mathrm{A}$, the cost, for the first year of the program, could be represented:

$$
\mathrm{X}(\mathrm{C}+\mathrm{P}+\mathrm{I})+\mathrm{A}
$$

In the years immediately following resettlement, an ongoing disbursement of funds would be necessary, beyond the outlay for the first year. Annual expenditures conceivably would decline over time. Some annual subvention, a fraction of $P$, might continue to be paid to resettled individuals, in order to facilitate transition into the new setting, but the subvention would be decreased incrementally year by year, over perhaps ten or twenty years, until phased out completely. The military component of $A$ might shrink, as stability in the effected territory increased. ${ }^{45}$

Resettlement in the past has involved deployment of force against civilians that can only be described as state sponsored terrorism on gigantic scale. This, to say the least, puts a cloud over the fact that the relocation of communities in some instances has removed inter-group flashpoints from the geopolitical map and calmed long volatile situations. Indeed, the means to the end have been one factor excluding demographic revision from conventional debate over security architecture. If the reprehensible means were separated from the desirable results, then the probability would increase for demographic revision to return to the repertoire of statecraft. Willingness to expend sizeable resources would be prerequisite to developing a mechanism for demographic revision in failed states that did not do unacceptable violence to the communities that its object was to help.

45. For an illustration of one possible process of transition to self-government and stability, see Thomas D. Grant, The Security Council and Iraq: An Incremental Practice, 97 Amer. J. InT'L L. 823, 826 (2003). 


\section{Remaking States in a New Era}

The United States and its allies now face the prospect of prolonged engagement in Afghanistan and Iraq. The long-term goal of engagement, after its initial object of thwarting a particular group of terrorists is achieved, will be to foster peace in those states and stability in the region. Ethnic hostilities have exercised their baleful influence in Afghanistan for a very long time, with the last twenty-two years witnessing a melee of multilateral insurrection and combat. Pashtun regions straddle the border between Afghanistan and Pakistan. Tajiks, Uzbeks, and Persians likewise look across Afghanistan's borders to neighboring states in which co-ethnics enjoy at least comparative peace and prosperity. Tribe, clan, faith, and ethnicity draw their own dividing lines, with internal political allegiances in places cutting across multiple categories. Other states that host antagonistic regionalisms, Nigeria among them, have also occasioned proposals for partition ${ }^{46}$ but, similarly, are too complex to be resolved without extensive study and debate. It would exceed the scope of a single article to assess the merits of remaking any particular state. That is for experts who know the regions in question best. Experts on Afghanistan come to different conclusions about the needs of the people in that country. ${ }^{47}$

In Iraq, where northern Kurds have governed their own territory over twelve years of uneasy peace and demonstrated restraint against old Arab tormentors in time of war, policy makers well may also consider the options. Would a wealthy Kurdistan and thriving city-state of Basra, sandwiching a disarmed and truncated Iraq be worse than the entire California-sized territory in chaos? ${ }^{48}$ Again, experts will disagree, and none can read the future.

46. See Okechukwu Oko, Partition or Perish: Restoring Social Equilibrium in Nigeria through Reconfiguration, 8 IND. INT'L \& Comp. L. Rev. 317, 321 (1998).

47. Stephen P. Cohen expresses the view that Afghanistan has a "finely developed sense of nation-hood." Stephen P. Cohen, The Future of Afghanistan: Hearing Before the House Comm. on Int'l Rel., 107th Cong. 15-18 (2001) (statement of Stephen P. Cohen, Senior Fellow, Brookings Institute). Dilip Hiro's analysis contrasts sharply. Dilip Hiro, Before They Can Build a Nation, Afghans Need a National Identity, WAsh. Post, November 18, 2001, at B2. Radical revision is becoming a publicly debated policy option. See Peter Schweizer, Partition Provides Best Afghan Solution, USA Today, October 29, 2001, at A15; Stephen Kinzer, Break Up Afghanistan? Why Not?, N.Y. Times, December 1, 2001, at A15.

48. See Ralph Peters, Why Must Iraq Stay Whole?, WAsh. Post, April 20, 2003, at B7. 
The premise is entrenched that the means often employed in the past to disaggregate divergent communities are inseparable from the result. The premise is, to say the least, difficult to test. In places where inter-community hostilities are sharp, leaving local populations to seek settlement of their differences often heightens the risk of violence, especially where conflicts between communities are unmanageable under the prevailing economic, social, and political conditions. Most of the worst cases of ethnic cleansing have taken place where attempted cohabitation has continued despite excruciating demonstrations of its failure. Hostility signals that conflicting groups should part one from the orher; they will not or can not; and violence escalates into a final paroxysm of forced population movement and even slaughter. A result, however, in many instances has been the establishment of a demographic disposition manifestly more conducive to stability and peace than the status quo ante. The means typically giving rise to this have been conflated with the result-thus a powerful discouragement from considering the result on its own terms.

Moving people in furtherance of the public good is not a measure unknown in established democracies. Laws of eminent domain and condemnation have rested on the realization that the state may identify needs that require its citizens to pull up stakes and go elsewhere. ${ }^{49}$ Before resorting to such laws, officials of the state would be politically imprudent, if not in breach of legal obligation, if they failed to explore alternative measures of less disruptive character. ${ }^{50}$ Once they

49. Writers have posited that governments in the municipal context enjoy an extensive right to eminent domain. See Bruce Ackerman, Private Property and the Constitution 190 n.5 (1977); Richard Epstein, Takings: Private Property and the Power of Eminent Domain 162 (1985); Margaret Jane Radin, Reinterpreting Property 136-37 (1994); Wendell E. Pritchett, The "Public Menace" of Blight: Urban Renewal and the Private Uses of Eminent Domain, 21 Yale L. \& Pol'y Rev. 1, 2 n.7 (2003). For the law in two states, see N.Y. Gen. Mun. Law § 696-b (McKinney 1987) (New York State statute pertaining to the right of municipalities to exercise eminent domain); MAss. Gen. Laws ANN. ch. 79, § 2 (Commonwealth of Massachusetts statute specifying officials authorized to exercise eminent domain); People v. Adirondack Ry. Co., 54 N.E. 689, 692 (N.Y. 1899), aff' 176 U.S. 335 (1900) (holding that eminent domain is an inherent right or inextinguishable attribute of sovereignty exercisable by the state or its authorized agent).

50. Yet policy makers would have to consider whether alienation of property is analogous to alienation of nationality. Relocation of persons after the exercise of eminent domain is incidental to the property transfer, but it would be the central fact of a policy of demographic revision and could, in instances, involve changes of nationality. The position, as often interpreted, is that each state is free to determine which individuals are its nationals and free also to revoke nationalitybut within limits of international norms, such as those set forth in the Universal Declaration of Human Rights, art. 15(2): “[n]o one shall be arbitrarily deprived of his nationality nor denied the 
choose to exercise the potent state right, officials should be fair in its exercise, particularly in the matter of compensation. In recent years, the United States and its allies have not identified international security interests of a scope and urgency that would impel commitment of resources to programs of foreign aid on the scale witnessed during reconstruction after World War II. Commitment on a similar scale would be necessary, however, if the international community were to seek to change the geography of population in Afghanistan and elsewhere and to do so in ways that make provision for the comfort and rights of the individuals affected. Compensation to individuals would have to accompany such remaking of failed states.

At a time when all aspects of international politics were overshadowed by the rivalry of two states armed sufficiently that a war between them might well have been tantamount to Armageddon, extreme caution was the order of the day. Fear that frictions in one corner of the world might spark an uncontrollable conflagration between the two superpowers lent support to a rule of overarching conservatism as regarded the identity and structure of states. The new security situation however differs radically from that between 1945 and 1989. Great powers no longer seek territorial revision or radical constitutional revision against other great powers. The leading states in the security system of the present are not ready to go to war against their peers. The great powers have recognized that they have a great deal that is worth protecting and that the other

right to change his nationality." State action in this respect may also be constrained by an international presumption against the legality of measures which result in statelessness-that is to say, deprivation of nationality where the individual so deprived does not have ready recourse to the assumption of a new nationality. See id. at art. 15(1) ("Everyone has the right to a nationality"); United Nations Convention on the Reduction of Statelessness, art. 7(1)(a) ("If the law of a Contracting State entails loss or renunciation of nationality, such renunciation shall not result in loss of nationality unless the person concerned possesses or acquires another nationality"). For the locus classicus of the proposition that each state is free to determine who are and are not its nationals, see Tunis and Morocco Nationality Decrees, 1923 PCIJ, Ser. B, no. 4, at 24. Finally, it is noteworthy that forced deprivation of nationality was a central part of the 'bantustanization' program under Apartheid in South Africa; black South Africans were declared 'citizens' of one of four putative 'independent homelands' or 'bantustans' - the Transkei, Bophuthatswana, the Ciskei, or Venda. This policy was condemned internationally. See John Dugard, South Africa's "Independent" Homelands: An Exercise in Denationalization, 10 Denv. J. Int'L L. \& Pol'y 11, 21-35 (1980); John Dugard, The Denationalization of Black South Africans in Pursuance of Apartheid: A Question for the International Court of Justice?, 33 Rev. Int'l Comm'n Jurist 49 (1984); Dugard, Recognition and the United Nations 81-82, 98-108 (1997) (on the Transkei in particular); Human Rights and the South African Legal Order 91-92,94-96, 110-11 (1978). 
great powers have practically unlimited capacity to do them harm. Great power conflict is thus less a threat today than it has been at any time in hundreds of years. The security threat at the moment, rather, comes from fractured and anarchic groups that abhor the status quo at least as much as did Napoleon or Hitler. A system that starts with the assumption of the immutability of state territorial and constitutional dispositions today faces the eroding influence of a much-changed political reality.

Threats spring from failed states. Denizens of failed states, frustrated with their position in the international system, lash out at the system itself. Even when the people of a failed state remain essentially pacific and do not themselves develop violent world-spanning visions like that of a bin Laden, the state in its crippled condition becomes the ideal host for terrorist organizations that do. However much there may exist shadowy networks of terrorists that operate without fixed homes, the security risk multiplies when such networks also enjoy the safe haven of an unmolested territorial seat. It may be possible for terrorists secretly to assemble in American or European cities and then execute acts of mass terror on those "enemy" shores. Full-scale training and weapons development, even amidst a western polity in which attitudes toward security are relaxed, would be extremely difficult. Some activities can be carried out under the noses even of the most vigilant, but other activities are simply too conspicuous to go unnoticed without the benefit of physical space and official cooperation of sovereign scope.

The litany of failed states is extensive-Somalia and Afghanistan are core examples of the form-states that have utterly ceased to function as states. Numerous other states fall along a continuum of failure. Colombia, Yemen, the Sudan, Mauritania, Haiti, Angola, Sri Lanka, Georgia, Cambodia, Tajikistan, Iraqthese belong to a growing category of country suffering serious deficits in internal stability. The crisis for the international system comes when domestic turmoil in such places spills over into the wider world. In an era when the failed state can provide sanctuary to terrorists and these terrorists well may acquire the means to do harm of terrible extent anywhere on the planet, neat division between the stability of particular states and global security architecture grosso modo is quite simply untenable. Thus, to contrast "preventing nuclear war and helping preserve global stability" against "dealing ... with a third tier of insecurity and violence-tangled ethnic struggles, civil wars, and failed states" ${ }^{\text {"1 }}$ deflects concentration from the

51. Jonathan T. Howe, The United States and United Nations in Somalia: The Limits of Involvement, 18 WASH. Q., Summer 1995, at 49. 
challenge at hand. In many failed states, a major source of domestic turmoil is the inability of divergent communities to live as aggregate populations in close proximity on the same territory. It is in light of this that disaggregation-the radical revision of community geography-may find advocates for its incorporation into global security architecture in the decades ahead.

Disaggregation of hostile groups, followed by a commensurate revision of constitutional arrangements on the territories they inhabit, may present an alternative approach to security. It has brought calm to countries and regions long plagued by inter-communal conflict. It runs against established norms and against the ordering structure on which the international community has rested for two generations. Only a bold reconsideration of international law and security architecture could make remaking states an accepted part of international life. 